\title{
An Ethical Assessment on the Management of Introduced Sika Deer (Cervus nippon) in Scotland; With Particular Reference to Hybridisation with Native Red Deer (C. elaphus)
}

\author{
Sarah Malcolm ${ }^{\mathrm{a}}$
}

\begin{abstract}
This review assesses the status and role of wild sika deer in Scotland's ecosystem. Sika deer pose a range of beneficial and detrimental impacts both economically and ecologically. One major damaging factor is the hybridisation with sympatric red deer, rendering sika deer a threat to the genetic integrity of red deer and consequently Scotland's native biodiversity. As an iconic and valuable component of Scotland's heritage, conservationists and the public generally feel that red deer should be prioritised above their non-native counterpart. Understanding the distinction between the roles of natural and anthropogenic hybridisation in evolution is important in the conservationist's ethical attitude towards management. This dissertation provides an evaluation of the interaction between ethics and policy to shed light on current and potential future management practices. The ethical viewpoint on these issues is particularly important in light of the fact that only scientific perspectives on sika and red deer hybridisation have been provided so far. Comparative management examples are reviewed to provide an improved understanding of sika deer management in Scotland. Anthropogenic hybridisation between invasive alien species and their native counterpart however, must be considered independently. Ultimately more research is needed to better predict the future outcome of hybridisation and introgression on Scotland's red deer stocks under various management approaches.
\end{abstract}

Keywords: Invasive Alien Species; Hybridisation; Wildlife Management; Ethical Management; Speciation

Sika deer (Cervus nippon) were imported into Britain from East Asia, approximately 150 years ago for aesthetic purposes (Swanson and Putman 2009). Following a combination of release and escape into the wild, a spectrum of beneficial and detrimental consequences has been recognised. Whilst stalking and venison production generate significant income and employment, the negative repercussions of sika deer on livestock, forestry and biodiversity are also substantial (Manchester and Bullock 2000). Throughout history man has manipulated the environment to suit what he considers productive and amiable (McNeely 2001; Goudie 2013). The importation of sika deer into Britain is one example of this. The domestication of landscapes and ecosystems (Kareiva et al. 2007) often involves the removal of species that cause 'harm' or are 'undesirable', whilst species deemed 'beneficial' are encouraged, transported and even modified. Invasive alien species (IAS) are species that are transported through human action across ecological barriers (European Commission 2013). Globalisation has led to an enormous increase in IAS (Hulme 2009), which frequently cause considerable ecological or financial damage (Kymäläinen et al. ; Lowe 1994; Abernathy 1994; Diaz et al. 2005). The Aichi 2020 Biodiversity Targets aims for controls to prevent the introduction and establishment of hazardous species (Convention on Biological Diversity), however, where prevention is not successful, alternative strategies are required. Human homogenisation is apparent in a variety of forms, including language, culture and genetics. This MacDonaldisation of society (Ritzer 1993) is comparable to that of our global fauna, as a direct result of globalisation.

Invasions of non-indigenous species are serving to break down previously biogeographically distinct realms of the world's biota (Vitousek et al. 1997; Goudie 2013) generating serious management and control challenges (Allendorf and Lundquist 2003). Hybridisation between non-indigenous and native taxa is a major threat to biodiversity as it can cause loss of fitness through outbreeding depression (Rhymer and Simberloff 1996) and in some cases, even extinction (Mooney and Cleland 2001). Hybridisation, often a natural process, occurs worldwide where two genetically distinct individuals produce offspring, yet becomes a conservation issue when it threatens a native species (Balharry et al. 1994). Like many IAS, sika deer in Scotland are an example of human-induced environmental change (Vitousek et al. 1997). Local hybridisation, and subsequent introgression, between invasive sika and native red deer (Cervus elaphus) is not a natural phenomenon. Introgression is already widespread in areas of Scotland (Senn and Pemberton 2009), therefore it is important to consider how to manage hybrids and introgressed individuals, and whether or not it is too late to achieve this effectively. Varying stages along the hybridisation continuum have different impacts on biodiversity and in turn affect management differently. It is therefore important to have sufficient knowledge of the ecology and evolution of both native and non-native taxa in a community context (Allendorf and Lundquist 2003). Anticipating the potential outcomes of hybridisation and likelihood of widespread introgression is vital in understanding the effects on biodiversity (Swanson and Putman 2009). Development of scientific, technical and institutional capacities to predict the threat from sika deer is crucial for planning and effectively implementing appropriate management measures.

There exists a considerable body of research on the ecological and economic implications of Scottish feral sika deer populations. However, conservation in the UK is no longer exclusively an economic issue, but also a social one, encompassing both political and human factors (Bremner and Park 2007). This review aims to provide a novel synthesis of the ethical dimension of managing sika deer populations in their non-native Scottish range, whilst also exploring the

a. School of Biology, Newcastle University, England

Contact: m_sarah@hotmail.co.uk 
wider public and scientific attitudes towards biodiversity conservation, and the division between natural and anthropogenic hybridisation. Society frequently looks to ecology for instruction when responding to IAS (Sagoff 2005). To determine the best method for sika management in Scotland, this review explores the existing management policies and the various parties involved, whilst providing an assessment on how anthropogenic actions, such as the introduction of species, impacts the ethics of management decisions. Deer management is expensive and time consuming, therefore it is important to consider the economic, environmental and ethical costs and benefits of management in order to answer the question 'why we should manage sika deer?' before answering 'how we should manage sika deer?' This review does not intend to list the various management policies; instead it aims to consider the interaction between ethics and science when deciding the legislative basis for invasive species policy.

\section{Is Hybridisation a Creative Force?}

Before implementing management on hybridising populations we must first analyse the positive and negative consequences of the hybridisation phenomeneon. The evolutionary significance of hybridisation in nature is considered by some as "merely disturbances in the on-going course of evolutionary differentiation" ( $\mathrm{Jr} 1970)$ and that "introgressive hybridisation seems to be a negligible source of genetic variation in animals" (Mayr 1970). This view is contested by others, particularly botanists, who consider hybridisation as a significant speciation process (Knobloch 1959); "the single most important factor in producing the necessary genetic variation for evolution" (Lotsy 1916).

Natural hybridisation has played and continues to play an integral role in the evolution and diversification of species (Allendorf et al. 2001). Hybridisation and reticulate evolution events exhibited in various plant species (Hewitt 2001) have been both frequent and important, for example, in the establishment of the new Louisiana iris species (Iris nelsonii) (Arnold 1993), resulting from hybridisation between the three Louisiana irises (I. fulva, I. giganticaerulea, and I. brevicaulis), at the site of their range overlap (Arnold 1994). Mammalian hybrid zones have been found to occur more commonly in nature than formerly thought (Shurtliff 2013) contesting Mayr's outdated belief that "successful hybridisation is indeed a rare phenomenon among animals" (Mayr 1970). The evolutionary consequences of natural hybridisation are abundant and varied; however, allowing species to progress naturally is not the same as anthropogenic hybridisation. Though nature is in a constant state of flux, if a given mutability is generated through human actions and not a naturally occurring phenomenon, it begs the question of whether we then have the right or even the responsibility to intervene.

Human mediated hybridisation is often regarded as 'genetic pollution' (Zachos and Hartl 2011). Although distinguishing between natural and anthropogenic hybridisation is vital for conservation, the division is often unclear (Allendorf et al. 2001). This difficulty in boundary distinction is exemplified in the changing Arctic environment, as a consequence of global warming, threatening polar biodiversity. An increase in range overlap between the sympatric grizzly (Ursus arctos horribilis) and polar bears (Ursus maritimus) has resulted in the formation of hybrids (Kelly et al. 2010). What is not ambiguous though, is that whether deliberately or inadvertently, trade and other anthropogenic impacts have increased the introduction of non-native species (Meyerson and Mooney 2007; Huxel and Hastings 1999), facilitating hybridisation between species that were otherwise geographically isolated. Subsequently hybridisation has become a common phenomenon in plants, birds, fish and various other taxa. Indeed, the threat to the genetic integrity of red deer would not exist under natural circumstances, as sika and red deer would have remained geographically separated (Milton 2000), rendering man's ethical responsibility toward both hybrid and sika conservation as unclear.

\section{Contested Prioritisation of Native Species}

Before seeking to evaluate the relative efficacy of various management strategies, it is important to firstly consider the ethical implications of culling and/or eradicating sika deer and their hybrid progeny in Scotland. Complications in our ethical responsibility concerning non-native species (NNS) and hybrids arise when they begin to outcompete or have deleterious effects on native species. Global damage caused by IAS accounts for $\sim 5 \%$ of the world economy and represents the second greatest threat to biodiversity after habitat loss (Butchart 2008). The Convention on Biological Diversity, through the Global Invasive Species Programme, aims to conserve biodiversity by minimising the spread and impact of IAS (UNEP 2005). A Plague of Rats and Rubbervines (Baskin 2002) highlights the negative implications that IAS can have on an area, as they often pose a threat to native biodiversity (Schlaepfer et al. 2010; McGeoch et al. 2010), and can cause significant losses both economically and with regard to natural resources (Reaser et al. 2007; Pejchar and Mooney 2009). Following the introduction of approximately 50,000 IAS (Pimentel et al. 2000), environmental damages and losses are estimated at roughly $\$ 120$ billion annually in the United States alone (Pimentel et al. 2005). Figure 1 demonstrated how species from the family Cervidae can cause relatively high impact on the economy, health and biodiversity.

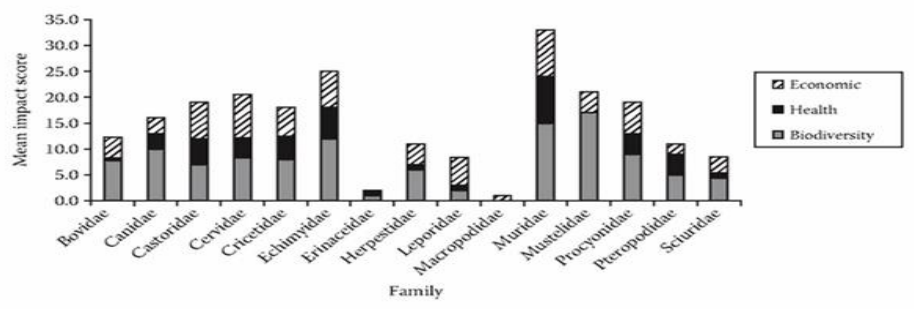

Figure 1: (Pimentel 2002) potential economic, human health and biodiversity impacts of the various families of mammalian IAS in Europe. Sika and red deer both belong to the family Cervidae which ranks relatively high in mean impact, particularly economically. (Data from (Nentwig et al. 2010) 
Humans have played a considerable role in accelerating the introduction rate of non-native species into new environments. Globalisation and international trade has facilitated the introduction and spread of non-native species (Meyerson and Mooney 2007), significantly altering environments worldwide (Lockwood et al. 2005; Hodder and Bullock 1997). Man's invasion of the Hawaiian archipelago, and subsequent introduction of a plethora of exotic species, has and continues to seriously threaten the survival of many of the native taxa (Vitousek et al. 1997; Simberloff and Genovesi 2013; John Ralph and Maxwell 1984). IASs are known to alter ecosystem processes, decrease native species abundance and richness via competition, predation, and hybridization, change community structure and alter genetic diversity (Manchester and Bullock 2000). Although introduced organisms may add to the overall species richness of an ecosystem, this can often come at the expense of rare native species, thus reducing native biodiversity (Sagoff 2005). It is therefore vital to understand whether the exotic species in question increases or decreases the species richness of natural environments when deciding on management policies.

The Convention on Biological Diversity holds that control or eradication of alien species should be applied to mitigate threat to ecosystems, habitats or species (Convention on Biological Diversity 1992). This however leaves unanswered the question of whether is it right to kill large numbers of individuals in order to protect another species. This ethical uncertainty often results in conservationists distancing themselves from arguments concerning the rights of individual animals, instead focusing on a broader picture of biodiversity conservation. Basing conservation management on a series of ethical absolutes would be impractical. A deontological approach must therefore be avoided and instead cost benefit analysis used by management to achieve a balance between the interests of welfare, finance and the desired conservation outcome. The Executive (2004) report stated that "We need to think in terms of landscapes and ecosystems, not just in terms of species and habitats." This essentially utilitarian approach is often adopted here whereby the net benefit to biodiversity is considered greater than any suffering inflicted on the individuals culled. This perspective would support the eradication of sika deer if necessary to preserve the genetic integrity of native red deer.

The harmful effects of hybridisation historically led to the extinction of many endemic populations and species (Allendorf et al. 2001). Hybridisation with invasive species may result in phenotypic alterations and hence change the ecology of a native counterpart (Senn and Pemberton 2009). The mixing of gene pools and potential loss of genotypically distinct populations can be particularly problematic for rare species (Rhymer and Simberloff 1996), as evidenced by the White-headed duck (Oxyura leucocephala). Following introduction of the Ruddy Duck (O. jamaicensis) from America into Great Britain in mid- $20^{\text {th }}$ century, populations proliferated across Western Europe. Introgressive hybridisation with the globally endangered (BirdLife International 2012) and native white-headed duck in Spain (Muñoz-Fuentes et al. 2005; Smith and Henderson 2007) resulted in the implementation of an eradication programme for the Ruddy duck and its hybrid progeny (Muñoz-Fuentes et al. 2007). A 95\% reduction of UK Ruddy duck populations by
2010 resulted in fewer transboundry effects of ducks arriving in Spain (Muñoz-Fuentes et al. 2013). The early implementation of the effective Ruddy duck control programme prevented extensive introgression occurring (Muñoz-Fuentes et al. 2007), highlighting the importance of effective management strategies.

Where early execution of management does not occur or complete eradication is inappropriate, alternative strategies are required. For instance, the reintroduction programme of critically endangered Red wolves (Canis lupus rufus) (Kelly et al. 2008) into North America is being thwarted by introgressive hybridisation with native coyotes ( $C$. latrans) (Adams et al. 2003) which invaded red wolves range. Hybridisation, believed to be anthropogenically influenced, is the primary threat to the persistence of wild red wolves (Kyle et al. 2008). An adaptive management plan has been implemented in the US to reduce hybridisation between red wolves and coyotes. Hybrids, branded 'Coywolves', and coyotes in the area are sterilised to prevent further hybridisation and introgression (Kyle et al. 2008). As introgression is already present in some red and sika deer populations (Goodman et al. 1999), effective management interventions to reduce further spread, and control existing populations are essential in preventing introgression spreading throughout the entire Scottish mainland red deer population.

Although the morality of killing large numbers of Ruddy ducks 'in the name of conservation' was not fully accepted by the public, conservationists argued that the ducks did not technically 'belong' in the UK. In a more everyday sense, this argument can be equated to a gardener's view on weeds being 'plants in the wrong place' (Milton 2000) and is arguably also applicable to sika deer in Scotland. Results from Selge et al. (2011) study on public and professional views on NNS concluded that method of introduction was an important factor when deciding on whether to support the control of species. Anthropogenic hybridisation is generally perceived to be of greater concern than natural processes, generating a strong sense of a moral responsibility to redress any detrimental imbalances (Selge et al. 2011). The partition between alien and natives is important from a conservationists' perspective. It is not the removal of alien species that is their primary concern, more the conservation of biodiversity, requiring species to be assigned value according to their rarity and vulnerability to extinction. The conservation of Red wolves and White-headed ducks are two examples of this. Native red deer boast healthy wild populations of approximately 10,000 (Swanson and Putman 2009) in Scotland. However, preventative management may be required to protect regional interests and future genetic integrity of red populations in Scotland.

\section{Management of Hybrids}

Introgressive hybridisation, most frequently observed in zones of geographical contact between allopatric taxa (Seehausen 2004), is the incorporation of genes from one species into the gene complex of another (Allendorf et al. 2001). It is the reverse of reproductive isolation and challenges the notion of species as biological units (Mallet 2005). Although hybridisation at an individual level is rare, particularly in animals, hybrids between many pairs of animal 
species are known, and are often fertile enough to backcross into their parental species (Mallet 2008).

Hybrid swarms occur when hybrids survive beyond the initial hybrid generation and progress to interbreed with other hybrid individuals or backcross with parent species. Due to endogenous or exogenous selection processes, first generation (F1) hybrids are generally less viable and fertile than the parental genotypes in parental habitats (Mallet 2005). The success of F1 hybrids determines whether occasional hybridisation events will lead to the development of hybrid zones or swarms through backcrossing (Figure 2). Hybridisation is not necessarily accompanied by introgression, even when hybrid vigour is apparent (Mayr 1970). Mules and hinnies (Equus asinus x E. cabaluus), except on extremely rare occasions, are unable to produce viable gametes. This post-zygotic isolation, caused by selection against genetic incompatibilities (Kirkpatrick 2000) prevents successful mating with either of parental types. Consequently genetic contribution to future generations is negligible, preventing the threat of hybrid swarms forming. This is not however the case in sika $\mathrm{x}$ red hybrids, where hybrid swarms have formed. Further research is required to predict which of the possible outcomes is most likely to occur.

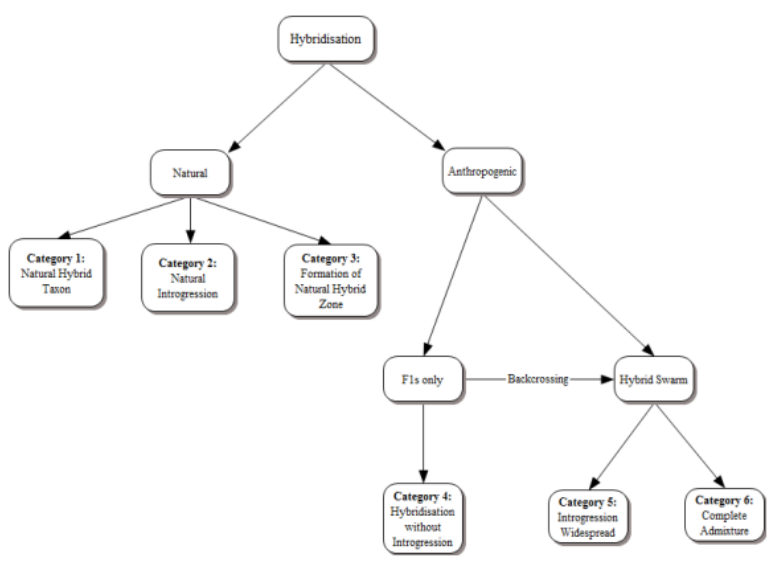

Figure 2: Reconstructed from (Allendorf et al. 2001) Provides a framework of the possible hybridisation categories. Categories 1-3 represent natural hybridisation events. The remaining categories (4-6) are distinguished as anthropogenic

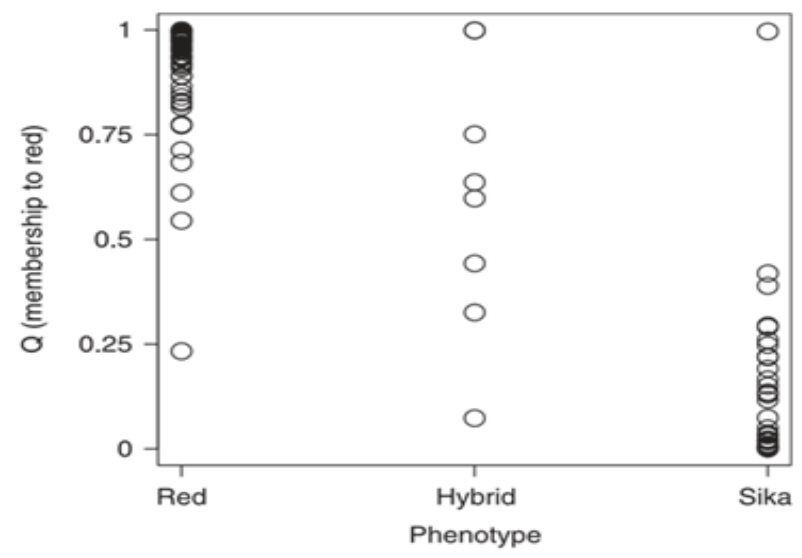

hybridisation, of which there are three types. All 6 types of hybridisation have different consequences from a conservation perspective, differing in their evolutionary significance, therefore requiring different management action.

In the absence of reproductive barriers in the wild there is little chance of maintaining a native species threatened with hybridisation (Rosenfield et al. 2004). However, when prezygotic isolation between two species by assortative mating is incomplete, the level of introgression can be mitigated by various selection pressures (Kirkpatrick 2000). The risk to the integrity of the Italian wolf (Canis lupus) gene pool though introgressive hybridisation with free-ranging domestic dogs (Canis lupus familiaris) has previously been a concern for conservation biologists (Vilà and Wayne 1999; Boitani 1992). Despite the presence of hybridisation however, genetic studies analysing mtDNA haplotypes failed to detect widespread introgression of dog mtDNA into the wolf population (Randi 2008; Vilà and Wayne 1999). This may either be a result of introgression in nature being countered by behavioural or selective constraints, making it rare for F1 hybrids to backcross into the wolf population (Verardi et al. 2006), or perhaps because hybridisation events are infrequent (Randi et al. 2000).

Hybridisation blurs the ecological, genetic and phenotypic boundaries between native and introduced species and consequent increased phenotypic similarity can lead to an increased likelihood of further hybridisation (Senn et al. 2010). Depending on the species, low rates of hybridization per individual can have important and significant evolutionary consequences as only few hybrids are required to provide a pathway permitting alleles to pass between species (Mallet 2005). Hodges et al. (1996) study on Louisiana irises demonstrates how the formation of F1 hybrids, even if rare, can catalyse higher rates of advanced generation hybrid production. Therefore management strategies may be required as damage can result from few hybrids in a population. In early stages, hybrids may be sufficiently rare, simplifying management. However, difficulty in identifying sika $\mathrm{x}$ red hybrids increases management problems. During Senn and Pemberton (2009) study in the Kintyre Peninsula, Argyll, Forestry Commission rangers asked to provide their own phenotypic assessment of culled deer ineffectively identified hybrids, even those genetically intermediate (Figure 3 ).

Figure 3: (Senn and Pemberton 2009) Estimated proportion of ancestry was plotted against the phenotype assigned by the ranger of 735 individuals in the Kintyre Peninsula. 513 individuals were designated as Red, 213 as Sika and nine as hybrids by the rangers who shot them, whereas there were a total of 51 individuals assigned genotypic hybrid status. 
The phylogenetic relationship between sika and red deer remains unclear (Kuwayama and Ozawa 2000). However, as lineages are estimated to have diverged less than 230,000 years ago (Polziehn and Strobeck 1998), the two species share a large proportion of ancestry (Matsunaga et al. 1998). The accumulated effects of recent introgression and ancestral polymorphism makes the positive identification of low grade hybrids challenging as ancestral polymorphism may be substantially contributing to apparent introgression (Senn and Pemberton 2009; Mims et al. 2010). Deer species of the genus Cervus are known to hybridise, producing fertile offspring (Biedrzycka et al. 2012), resulting in an increased frequency of introgressed alleles within each population. Consequently hybrid can reach sufficient densities to generate complex crosses between themselves. Positive identification of low grade sika $\mathrm{x}$ red hybrids has proven challenging, as it can be hard to distinguish between introgression and genuinely shared ancestry (Perez-Espona et al. 2009). Accurate evaluation of hybridization or introgression can be achieved through rigorous molecular or genetic tests (Mallet 2005) distinguishing contributions of ancestral polymorphism from current hybridisation. The use of molecular genetic techniques to analyse hybrid zones are increasingly common (Boecklen and Howard 1997). Goodman et al. (1999) study on deer populations in Argyll used 11 microsatellite markers and mtDNA taken from individual deer samples. Results showed $40 \%$ of deer carried apparently introgressed alleles in areas of overlap between the two taxa. However, the selected loci had different allele frequencies in the two species, thus generating inflated estimates of hybridisation. Senn and Pemberton (2009) subsequent study selected 22 loci which did not share alleles, to prevent overestimates of hybridisation as ancestral polymorphism. Significant levels of introgression are known to have occurred in West Loch Awe. This highly clumped distribution is potentially due to one or two particularly successful sika stags generating multiple F1s simultaneously (Senn and Pemberton 2009).
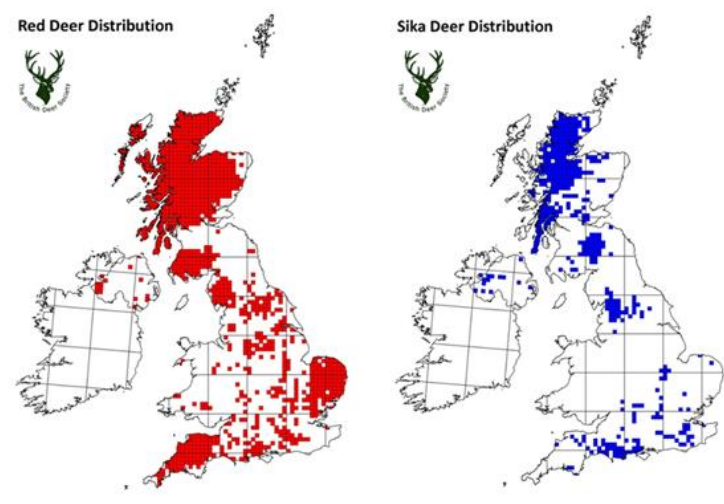

Figure 4 \& 5: Maps showing red (4) and sika (5) deer distributions across the United Kingdom. Data in the above maps is from a survey by the BDS in 2007. It is clear that there is much overlap of the two taxa in the Scottish highlands.

Hybridisation is believed to occur most frequently in areas where the two taxa overlapped for the longest (37.9\%) (Senn and Pemberton 2009). Sika deer range covers $\sim 40 \%$ of Scotland, (See Figure 4) overlapping significantly with red deer range. The pattern of introgression varied significantly across sites during Senn and Pemberton's study in the Kintyre Peninsula. Hybridisation rates were considerably more extensive in West Lock Awe than neighbouring Eredine/Birdfield, potentially due to occasional and irregular hybridisation events. Although introgressed individuals were most common in Knapdale, where the two species have overlapped the longest, hybridisation here is young. The effects of initial random hybridisation events may yet be dominated by the effects of exogenous and endogenous selection (Barton 2001).

Introgression may lead to either merging of hybridizing forms or the reinforcement of reproductive barriers through selection for assortative mating (Largiadèr 2007). Assortative mating maintains divergence by preventing hybridisation occurring between some populations and groups (Kirkpatrick 2000). If populations maintain generally strong assortative mating and hybridisation events remain rare, red-like and sika-like populations could persist indefinitely as separate entities. However, assortative mating is not reliable in natural circumstances and assortative mating preferences may be lost if multiple hybrids occur in a population. Increasing phenotypic similarity is likely to facilitate further break down in assortative mating between the two hybridising taxa (Senn 2009). As consecutive generations of hybrids accumulate within a population, the proportion of individuals of hybrid origin increases whereas the proportion of parental individuals progressively reduces (Allendorf et al. 2001). After several generations a hybrid swarm may be produced, where all individuals are of hybrid origin. Hybrid swarms can form even where there is selection against hybrids, because each individual in the swarm will be hybrid (Allendorf et al. 2001).

Introgressive hybridisation was not expected to occur between red and sika deer, due to the disparity in body size (Ratcliffe 1987). Although most sika and red populations are believed to exhibit strong assortative mating, with hybridisation occurring rarely, around one in five hundred to a thousand mating events (Goodman et al. 1999). Introgression is recorded in the wild at multiple locations in the United Kingdom (Senn 2009; Goodman et al. 1999; Putman and Hunt 1993), raising concern that breakdown of assortative mating and thus introgression could occur across sika and red deer ranges, over time spreading across entire Scottish mainland populations at similar levels those in the Kintyre Peninsula (Senn and Pemberton 2009). Populations can be recovered by the removal of hybrids if a reasonable number of parental individuals remain (Allendorf et al. 2001). It is therefore vital to understand the spatial patterns of introgression to predict what areas are of greatest conservation concern. Using data from the National Biodiversity Network (NBN) to plot a map of range overlap between the two taxa may prove useful in predicting where hybrid swarms are most likely to occur (See Figure6). 


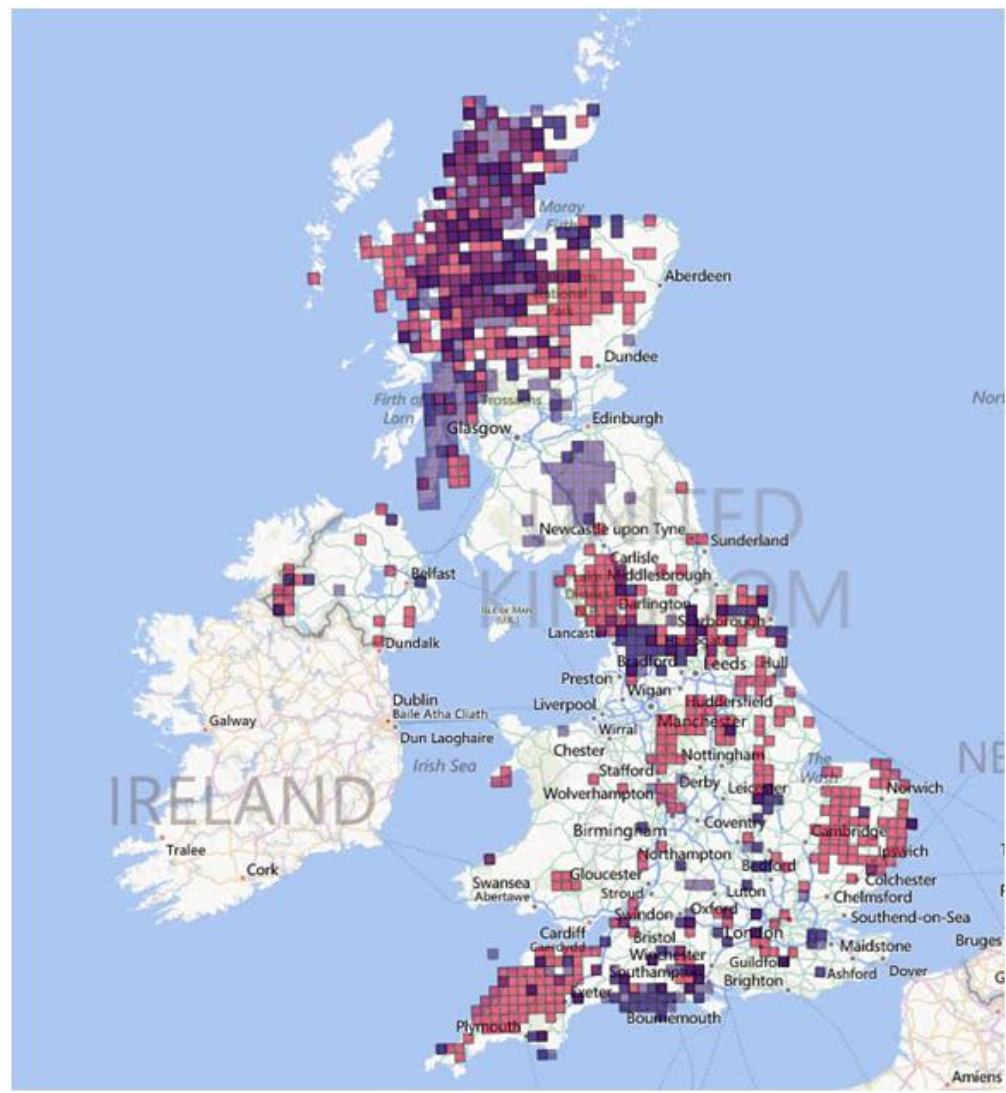

Figure 6: NBN gateway interactive map. Sika (light purple) and red (red) overlap (dark purple). Data used was collected between 2000 -2014. Provides an insight into the level of range overlap between red and sika deer in their Scottish range.

\section{Monarchs to Mongrels}

Edwin Lansteer's 1851 painting assigned the title of "Monarchs of the Glens" to Scotland's iconic red deer. Parodying this, Josephine Pemberton labelled sika $\mathrm{x}$ red hybrids as 'Mongrels of the Glens' (Bourton 2009). Although genetically dissimilar it is important to understand the distinction between hybrids and their parental taxa in ecology and behaviour, and how this will affect population dynamics. Introgressive hybridisation has the potential to reduce the adaptedness of red deer to their local environment. These genetic effects may cause fragmentation, resulting in reduced genetic variation following genetic bottlenecks (Manchester and Bullock 2000), compromising their 'Monarch' status.

Although red deer generate costs to the Scottish economy through agricultural and forestry damage, the also play both direct and indirect roles in benefitting the economy of rural areas in Scotland. Whilst exploitation through stalking remains an important source of income and employment, non-consumptive uses such as wildlife tourism are additionally important (Macmillan and Phillip 2008). Stalking estates in Scotland account for $\sim 43 \%$ of all privately owned rural land (MacMillan 2004) (See Figure 7). Sexual success in both male and female cervids is linked to body size (Clutton-Brock 1989). As hybrids are often intermediate size between sika and red, they are likely to show increased breeding success in sika populations compared to red, which would affect population dynamics. Although there is no evidence yet that hybridisation has affected condition or pregnancy rates in either population (Senn 2009), if the sika trait of reduced birthing interval were to introgress into red hinds, increased reproduction within red populations would exacerbate existing management problems. This highlights the importance of understanding how the genetic and phenotypic characteristics of deer affect reproductive output and consequent population dynamics. Admixture of sika and red populations may result in reduced trophy value; since sika have much smaller antlers than red, the estimated revenue for each deer shot is likely to depreciate, directly impacting the stalking industry.

The threat to Scottish red deer integrity is important both economically and culturally (Pérez-Espona et al. 2013). It is necessary therefore to consider how the fitness of hybrid individuals compares with that of their parental taxa when predicting how the outcome of hybridisation will affect red deer. Propagule pressure, often known as introduction effort, is the combined measure of the number of individuals of a species released into non-native area. It is believed to provide a consistent explanation for invasion processes, playing a key role in the successful establishment of an IAS (Lockwood et al. 2005; Colautti et al. 2006). This alongside knowledge of the taxonomy of the respective species is prerequisite in predicting sika and hybrid future status and impact in Scotland. 


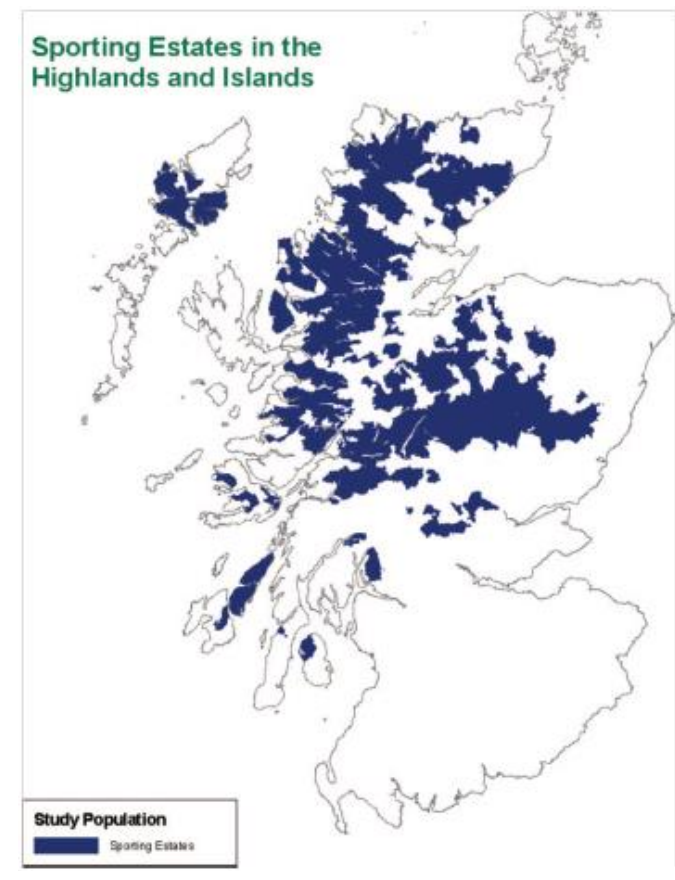

Figure 7: Distribution of sporting estates in Scotland (MacMillan 2004); Source (Higgins 2001)

\section{Restoring the Balance of Nature}

Man globally utilises numerous goods from ecosystems, often referred to as ecosystem services (Assessment 2005), which are derived from the biodiversity of an area (Hussain and Tschirhart 2013). Environmental manipulation to suit to our demands frequently jeopardises these services (Cardinale et al. 2012), creating or exacerbating management problems. The extent and significance of the human global impact on ecosystems is referred to as the Anthropocene, which commenced following the start of industrialisation in the 1800s (Steffen et al. 2007; Crutzen 2006; Steffen et al. 2011). The expiration of large apex predators throughout much of their historical range (Mech 1995) is just one example of impact from human involvement (Strong and Frank 2010). Subsequent to the removal of predators, there are often increased population densities of large herbivores. For instance, the native Lynx (Lynx lynx), Brown bear (Ursus arctos) and Grey wolf (Canis lupus), predators of red deer, were hunted to regional extinction in the British Isles (Yalden 2010). The release of deer populations in Britain from predation has enabled existence at high densities (Gorman 2007), their populations only limited though hunting or culling by man.

Humans actions are undeniably impacting biological evolution and biodiversity (McMahon et al. 2012) and significantly altering ecological balances in nature globally (Chapin Iii et al. 2000). Consequently, it is important to consider whether there is an ethical responsibility to restore a balance in nature where possible, or whether interference will cause further damage. Current proposals for Grey wolf reintroduction in Scotland would have significant ecological impacts (Nilsen et al. 2007), potentially serving to restore the balance of community structure and function (Gorman 2007), whilst providing a management method for sika deer. Wolves may have non-lethal effects on the Scottish ecosystem, similar to those in Yellowstone National Park (Ripple and Beschta 2007, 2012), where risk of predation may alter prey behaviour and habitat use (Schmitz et al. 1997). Additionally, lethal effects may lower overall deer population densities (Hebblewhite et al. 2005), which would serve to reduce grazing pressure and the significant financial burden reaching cull targets for both red and sika hinds set by the Deer Commission for Scotland (DCS). The use of the Markov chain predator-prey model was used in Nilsen et al. (2007) study to predict the probable consequences of wolf reintroduction on red deer populations. Brown bears and Wolves were known to predate sika deer in their native Japanese archipelago (Ripple et al. 2010; Kaji et al. 2004). Regional extinction of the Grey wolf in Japan (Mech and Boitani 2013) resulted in increased sika deer populations (Ripple et al. 2010). A similar test on how sika deer populations may be affected by wolf reintroduction in Scotland could prove useful in predicting its merits as a potential management strategy.

Public support is important in the success of management and reintroduction programmes. If the British public perceived wolves to pose potential threats to human populations, reintroduction proposals may not be supported (Wilson 2004). The misconceived old world view of the dangers of wolves, provoked by exaggerated myths such as 'Little Red Riding Hood' (Geist 2007), is not factually borne, as between 1952 and 2002 there were a total of eight fatal wolf attacks on humans in Europe and Russia and none in North America during the twentieth century (Linnell et al. 2002). Since wolves recolonized France in the late 1980s, after considerable absence, there has been no reports of attacks on humans (Linnell et al. 2002), whereas domestic dogs are reported to attack around 210,000 people per year in England alone, with five fatalities between 2007 and 2012 (DEFRA 2012), the majority of on children (Schalamon et al. 2006; Mullins and Harrahill 2008).

Although rural and urban attitudes varied in Nilsen et al. (2007) survey, $43 \%$ favoured the reintroduction of wolves into the wild, $35 \%$ favoured reintroduction into fenced parks whilst only $14 \%$ favoured none. Public attitudes and the potential lack of conflict between wolves and hunters make wolf re-introduction an interesting and plausible management and conservation option. Further scientific research is required to understand what ecological effects wolf reintroduction would have on the density and behaviour of red and sika deer in Scotland (Manning et al. 2009). Results from Nilsen et al. (2007) study suggest the presence of wolves would overall be economically beneficial for deer estates. Wolves may also provide selection pressure against sika $\mathrm{x}$ red hybrids in Scotland. Although re-introduction of wolves remains contentious, as it would increase cost through livestock mortality, reintroduction would aim to preserve Scotland's heritage and restore the balance of nature. Although this management proposal may not remove sika deer entirely, it is likely to reduce population density and potentially provide selection pressure against hybrids, encouraging sika and red taxa to remain genetically distinct.

\section{Who Manages Deer}


The Code of Practice on Deer Management was introduced following the Wildlife and Natural Environment (Scotland) (WANE) Act 2011 stating that "sustainable deer management is about managing deer to achieve the best combination of benefits for the economy, environment, people and communities, for now and for future generations". Although a comprehensive framework of policy and guidance is provided, input through many sectors with varying incentives renders policy making a complex issue. In order to be effective and sustainable, deer management must appropriately balance the inevitable conflicts between economic, environmental and social objectives.

Wild deer in Scotland are res nullius, meaning they are not owned by anyone; all rights to kill or take deer lies with the land owner. Subsequent to the enactment of the WANE Act 2011, the management of Scottish deer populations, although constrained by legislation, is carried out under the Voluntary Principle (Code of Practice on Deer Management). Despite being contested by some as a free-for-all, the Association of Deer Management Groups (ADMG) believes the Voluntary Principle provides an inclusive approach to deer management. As a shared resource, it is important that deer are managed collaboratively, through the allocation of cull targets based on percentages from regular population counts (Clutton-Brock 1989). Wild deer populations are managed by an assortment of organisations and individuals to achieve management aims (See Table 1). Flexible management enables populations to be managed according to the density and impact they have in a given area. The number of individuals that require culling to stabilise the population involves adjusting to variation in rates of recruitment and mortality (Clutton-Brock 1989). The establishment of over seventy Deer Management Groups (DMGs) in Scotland provides a collaborative approach to deer management, necessitated by the ability of deer to freely cross land holding boundaries (See Figure 8). Accurate and precise knowledge of deer population size and distribution, crucial for effective management schemes (Marques et al. 2001), is achieved through a coordinated annual deer count providing a basis for assessing the cull required. Information on sex and age structure of populations is integral to understanding population dynamics, and resultant management impacts. Effective management requires continued monitoring to determine rate of population change and patterns of spread.

The DCS, in association with $\mathrm{SNH}$, developed the Code of Practice by drawing knowledge from both a steering group, comprised of Deer Commission Scotland (DCS), Forestry Commission Scotland (FCS) and SNH, and an advisory group with representatives from various organisations holding interest in deer management. DMGs are often subdivided for practical purposes as landholders have disparate land use objectives and deer management depends largely on what is aimed to be achieved on the land. An increasing number of estates are owned by charitable organisations, environmental NGOs, community bodies and government bodies such as the $\mathrm{SNH}$ and the FCS. The effect of this recent mixture of land ownership on the landscape and environment is yet unclear, but may affect sika deer population distributions and management.

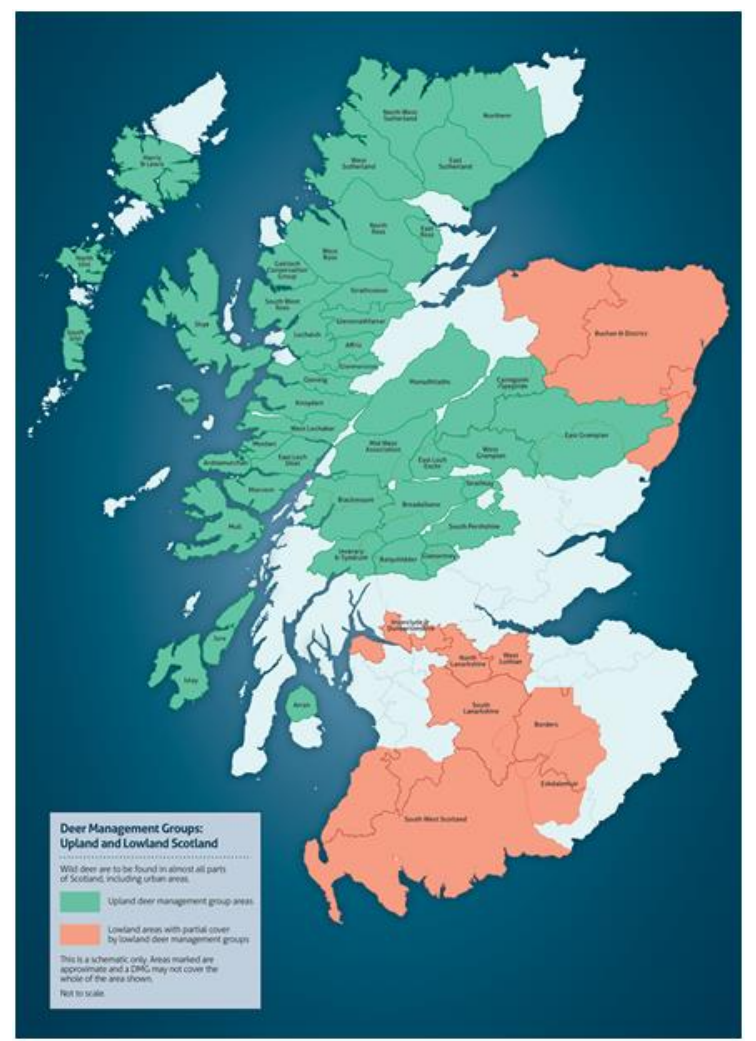

Figure 8: Distribution map of Deer Management Groups in Scotland comprised of estates and other landholdings, which manage wild deer populations as a mutual resource. DMG members carry out annual coordinated counts of populations and agree on annual cull targets. (Association of Deer Management Groups)

\section{Existing Management}

Scottish Natural Heritage (SNH) have a statutory responsibility to "ensure deer are being managed effectively, by everyone involved, in a way which takes into account the various aims and interests that exist, and does not unnecessarily compromise the welfare of wild deer. "Without control, growing deer numbers would cause increasingly significant economic loss and environmental damage. Undergrazing can also be detrimental; therefore the optimum density of deer populations must be determined for a given environment. Possible displacement may result following culls into protected sites such as Special Areas of Conservation (SACs) and Sites of Special Scientific Interest (SSSIs). Detailed knowledge and monitoring of movement patterns, accompanied by responsive action is therefore required. 


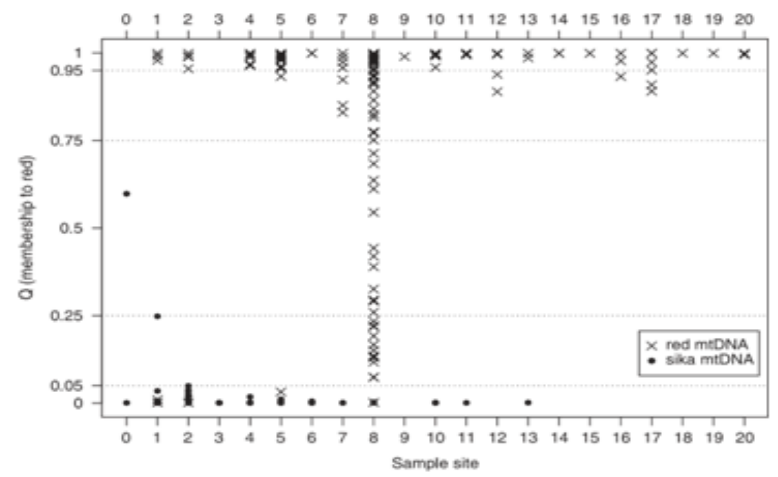

Figure 9: The proportion of ancestry (Q) for sample individuals at 20 sites within the Kintyre Peninsula, Scotland. Individuals are coded according to mtDNA haplotype. Note that in upper and lower regions of the graph, many points may overlap. Horizontal dashed lines represent cut off points for ( from bottom to top) 'pure' sika, sika-like hybrids, intermediate hybrids, red-like hybrids and 'pure' red deer (Senn and Pemberton 2009).

Understanding why some sika and red deer populations have hybridised while others have not may prove influential in management decisions. Ratcliffe (1987) suggests occurrence of hybridisation is most likely in areas where red or sika stags are colonising areas of the alternative taxon, so are denied opportunity to breed readily with conspecifics. Colonisation factor may be an important factor in hybridisation (Swanson and Putman 2009). Biedrzycka et al. (2012) study on Eastern European populations, using mtDNA data, discovered hybridisation most frequently occurred between sika stags and red hinds. As hybrid mtDNA is inherited from its maternal species (Wirtz 1999), analysis of mtDNA in deer populations in the Kintyre Peninsula allowed Senn and Pemberton (2009) to determine that most introgression occurred from red into sika (Senn and Pemberton 2009) (See Figure 9). Initial hybridisation events are likely to ensue between resident red hinds and sika stags migrating into the area. Sika stags are aggressive during the rut (Haanes et al. 2010) and lack of female mate choice in Cervids enables any behavioural mating barriers to be broken. One possible management method proposed is the active control of pioneering sika stags transgressing boundaries to mate with red hinds (Ratcliffe 1987). The annual selection and culling of transgressor males and hybrid or intorgressed individuals would not provide a long term conclusion to management.

Maintaining separate red and sika populations where possible may prove effective in mitigating hybridisation. Following revision of the Wildlife and Countryside Act 1981 (Order 1998) translocation of sika deer into areas outside their existing range is illegal. An alternative management strategy for sika deer is through habitat control; since sika deer thrive in areas of good forest cover (Swanson and Putman 2009), blocking corridors of forestry plantation and restricting afforestation may prevent sika deer spreading into remaining populations of 'pure' red deer. Alongside this, the physical barrier of properly erected and well maintained fences appears to be an effective non-lethal measure to manage deer densities and movements. Fencing permits different land uses to coexist within or amongst landholdings, protect public safety and allow changes to habitat such as woodland. Therefore use culling combined with barriers and habitat control could be regarded as the best management option.

Table 1: Contains the various organisations involved in the management of wild deer in Scotland, and a brief overview of their objectives

\begin{tabular}{|c|c|c|}
\hline Organisation & Category & Objectives \\
\hline $\begin{array}{l}\text { Deer Commission for } \\
\text { Scotland (DCS) }\end{array}$ & Statutory & $\begin{array}{l}\text { Ensure deer managed effectively. Responsibility to further } \\
\text { conservation, control and sustainable managenent }\end{array}$ \\
\hline $\begin{array}{l}\text { Scottish Natural Heritage } \\
\text { (SNH) }\end{array}$ & Statutary & $\begin{array}{l}\text { Promotes care and sustairable use cf natural heritage SNH } \\
\text { with input from stakeholders, has produced a Code of } \\
\text { Practice on Deer Management. Sets out proposed actions } \\
\text { in exercising their deer remit and continuing the work of } \\
\text { the Deer Comm ission for Scotland, and how these fit with } \\
\text { strategic priorities. }\end{array}$ \\
\hline $\begin{array}{l}\text { Forestry Commission } \\
\text { Scotland (FCS) }\end{array}$ & Statutory & $\begin{array}{l}\text { Ains to protect and expand Scotland"s forests and } \\
\text { woodlands. }\end{array}$ \\
\hline \multirow[t]{2}{*}{$\begin{array}{l}\text { Association of Deer } \\
\text { Maragement Groups } \\
\text { (ADMG) }\end{array}$} & \multirow[t]{2}{*}{ Vohuntary } & $\begin{array}{l}\text { Works closely with BDS to carry out coodinated counts of } \\
\text { deer in given areas annually. Population surveys provide a } \\
\text { basis for assessing the cull required to ensure that deer are } \\
\text { managed sustainably whilst also meeting the combined } \\
\text { objectives of groupmem bers. The anmul cull is agreed } \\
\text { among members of each }\end{array}$ \\
\hline & & $\begin{array}{l}\text { Deer Managenent Group (DMGG). DMGGs coenprise groups } \\
\text { of estates or other landholdings that share access to a } \\
\text { discrete population or herd of deer mana ged as a common } \\
\text { rescurce (See Figure 8) }\end{array}$ \\
\hline $\begin{array}{l}\text { The British Deer Society } \\
\text { (BDS) }\end{array}$ & Charity organisation & $\begin{array}{l}\text { Ains to promote deer welfare in today's current } \\
\text { envircment and to ensure that future for subsequent } \\
\text { generations is secure by working to achieve the best } \\
\text { management principles. }\end{array}$ \\
\hline $\begin{array}{l}\text { British Association for } \\
\text { Shooting and Conservation } \\
\text { (B.ASC) }\end{array}$ & Mem bership based & $\begin{array}{l}\text { Encourages shooting and wetl-being of the countryside } \\
\text { "promotes sustirable deer management across the UK by: } \\
\text { providing advice to members con habitat and species } \\
\text { managenent developing and supporting best practice. } \\
\text { offering deer stalking opportunities and influencing } \\
\text { govermment policy in order to protect shooting." }\end{array}$ \\
\hline
\end{tabular}


As discussed earlier, there are no natural predators of deer populations in Scotland, causing deer densities to be close to the food-limited carrying capacity. Borkowski (2000) study on sika deer in Japan's Tanzawa Mountains found that food biomass was important in determining group size. Intraspecific competition combined with interspecific grazing competition with livestock may result in starvation of individuals, whilst also initiating animosity among farmers if there was no management. Deer populations are in part managed by the identification and culling of unhealthy individuals that may be suffering from disease, malnutrition or injury. SNH advocates that deer prevented from accessing the areas they are dependent on for forage or shelter, as a result of barriers such as fencing, should be culled to minimize negative impacts of deer welfare.

\section{Is Culling Beneficial to Deer Welfare?}

"Conscience implies a sense of duty, and this infers a moral obligation and a human responsibility towards animals... which have been affected by man's environmental modification."

- Charles Hume - Conover2001?

As a result of humans expanding populations and increasing control over environments, man has a significant influence on the welfare of many wild animals (Kirkwood 1992). Where wildlife causes damaged to human livelihoods 'lethal control' measures are commonly taken (Woodroffe et al. 2005). Human wildlife conflict can also be regarded as a form of unjust persecution. Changing attitudes towards the extent of man's responsibility for wildlife welfare renders wildlife management is an increasingly social issue, encompassing human and political factors. Bremner and Park (2007) study on public attitudes regarding the management of invasive NNS in Scotland surveyed 248 randomly chosen members of the public. A significant $87 \%$ agreed that 'controlling some wildlife (both native and non-native) is necessary to help conserve the environment'. In relation to NNS effects on native species; $78 \%$ agreed that "non-native species should be controlled or eradicated where they do damage to any native Scottish species" increasing to $84 \%$ if the native species was threatened. Importantly, the methods used for control affected the level of public support.

Public opinions are influenced heavily by animal welfare, which arise in management when deer escape wounded or have a protracted death. Bradshaw and Bateson (2000) study on 372 red deer killed by stalkers showed a mean of $7.5 \%$ survived more than two minutes after being shot and $3.5 \%$ escaped wounded. Additionally, culling stags post rut may disturb non-target males, reducing their feeding at a time where they are replenishing fat stores reduced during the rut. Culling hinds generates significant welfare impacts for any dependant juveniles, which will either starve or have much reduced likelihood of survival. According to best practice management, all orphaned calves should be culled. When a mature hind that has been culled is discovered to be lactating, effort should be made to find and cull the juvenile. The SNH highlights that fencing must be integrated into a wider programme of deer management and deer dependant on the fenced off area should be culled. Knowledge of wintering sites is crucial in deciding what level of compensatory cull is required. If a fenced off area is heavily used by hefted hinds, they should be culled along with their dependents, or an alternative shelter should be made available to reduce the level of compensatory cull. The Deer (Scotland) Act 1996 includes the various legislation and offenses relating to conservation, control and sustainable management of deer, combined offenses relating to deer welfare.

Peter Singer, following a utilitarian philosophy, highlights that welfare issues can be inflicted on individuals through suffering caused when conspecifics are culled (Singer 2011). This phenomenon is known in various species such as African elephants (Loxodonta africana) (Bradshaw et al. 2005; Byrne and Bates 2011) among others (King 2013). Although deer may not 'grieve' the loss of conspecifics, the mental welfare of deer is not fully understood. As a prey species it is largely accepted that deer have evolved to cope with stresses associated with predation and loss of group members. Farmed deer are culled by a close range shot to the head, often whilst feeding. Those witnessing the death of conspecifics did not appear distressed (Bateson 1997). Due to the absence of natural predators, wild Scottish deer populations are not well adapted to cope with the level of activity imposed when hunted with hounds as a result of their evolutionary and life histories (Bateson and Bradshaw 1997). This may prove similar if wolves are reintroduced. It is important to assess the ethical dimensions of management associated with welfare when determining the best overall strategy.

\section{Conclusion}

As a destructive force in nature man inherits an ethical obligation to conserve ecosystems, particularly when a threat to biodiversity is considered to derive from human actions. To disregard the diversity of life would be myopic from both a practical and moral perspective (Wilson 1999) as biodiversity has both instrumental and intrinsic value. The former is both in the sense of the numerous eco-system services it provides, as well as the fact biodiversity serves as a prerequisite for a sustainable planet (McKee 2005). Increasingly, natural hybridisation is regarded as a creative force in fauna as well as flora. This stands opposed to a somewhat outdated understanding in which it is considered an unnatural breakdown of isolating mechanisms. Recognition of the historically significant role of hybridisation as a creative evolutionary process (Hochberg and Gotelli 2005), has led to a revaluation of many policies (Allendorf et al. 2001). This is exemplified in the withdrawal of the hybrid policy of the US Endangered Species Act of 1973, which implied that the conservation value of hybrid species was less than native species (Mallet 2005). Anthropogenic hybridisation however, is regarded differently by conservationists, with negative attitudes illustrated through various case studies discussed previously, and where management policies are employed to reduce or prevent hybridisation and introgression. When conservation problems arise as a result of human agency, a sense of responsibility to protect species at risk, rectify human induced environmental damage and to restore the natural order where possible is often felt (Aronson et al. 2006; Katz 2009). These ethical and ecological issues provide an answer to the question proposed earlier: "why should we manage sika deer'? 
As an island, with comparatively low vertebrate faunal diversity, Britain is at high risk of successful invasions relative to other countries (Pimentel 2002). Additionally, the increasing pace of human introductions requires Britain to take greater action in order to protect native taxa from IAS. Whilst the removal of IAS is not the primary objective of conservationists, their overarching mission to protect biodiversity often leads to the removal of unwanted species that are economically and environmentally harmful. Some NNS are widely accepted as part of UK biodiversity, such as rainbow trout (Oncorhynchus mykiss) and sweet chestnut (Castanea sativa). This 'pick and choose approach' is demonstrated by conservationists and their ability to decide which species requires control, and the level of control appropriate. This is largely contingent on the positive and negative contributions of a species. Conservation policy is largely determined on the perceived economic costs and benefits (Lévêque and Mounolou 2004; MacMillan and Phillip 2010), with moral and ethical grounds essentially take a secondary role in influencing policy decisions (Ninan 2006).

The threat to biodiversity posed by IAS to British ecosystems receives considerable public attention; featuring regularly in the news with headlines such as: "EU blacklist to stop spread of alien species" (Marshall 2014), "Alien Invaders Threaten Urban Areas" (Kinver 2013) and "Alien Invaders Wage 'Biological War' on Natives" (McGrath 2013). These generalisations are unhelpful at a practical level as threats must be understood at a species level. Although Scotland currently boasts healthy red deer populations, hybridisation studies suggest that there is a considerable risk to the future genetic integrity of this species if appropriate management is not enacted. The UN Convention on Biological Diversity stated in their 1992 report that "lack of full scientific certainty should not be a reason for postponing measures to avoid or minimise a given threat". Once hybridisation has begun it is often challenging to stop (Allendorf et al. 2001), therefore a 'guilty until proven innocent' approach may be required as a preventative strategy (Nentwig et al. 2010) to safeguard the population of red deer before they lose their genetic distinctiveness, leaving no pure natives (Huxel and Hastings 1999). Delaying active management may reduce the likely success of future management attempts.

After considering why management of sika deer is required, the issue of 'how we should manage sika deer' can be addressed. Policies concerning hybrids must be flexible; recognising that each situation involving hybridisation is

\section{References}

Abernathy K (1994) The Establishment of a Hybrid Zone between Red and Sika-Deer (Genus Cervus). Molecular Ecology 3:551-562.

Adams JR, Kelly BT, Waits LP (2003) Using faecal DNA sampling and GIS to monitor hybridization between red wolves (Canis rufus) and coyotes (Canis latrans). Molecular Ecology 12:2175-2186.

Allendorf FW, Leary RF, Spruell P, Wenburg JK (2001) The problems with hybrids: setting conservation guidelines. Trends in Ecology \& Evolution 16:613-622. different (Allendorf et al. 2001; Sagoff 2005). Whilst drawing from similar examples is useful, a specific strategy is required as general rules are unlikely to be effective. The continually evolving subject of sika deer management is multifaceted, involving conservation, economics and ethics. Many parties with varying interests render aims and methods of management complex; "...because of the need to balance the environmental, economic and deer welfare objectives of the Scottish nation with the objectives that private landowners have for forestry, agriculture, sporting and other forms of land use" Michael Russell, Minister for the Environment (Scotland's Wild Deer 2008). That the most appropriate course of action remains unclear means further research, including ecological impact assessments, are required in order to evaluate the potential repercussions of each proposed management option (Treweek 2009) on the Scottish ecosystem. Although legislation to protect pockets of pure red populations on the Hebridean archipelago is beneficial, the genetic integrity of mainland red deer populations remains at risk. Introgression may compromises the genetic integrity of red deer stocks, reducing trophy quality. The level of economic damage this may have on the Scottish deer stalking industry is unknown, further research is therefore required.

The available scientific literature on sika and red deer hybridisation provides insight into ecological processes. However, this dissertation provides a novel synthesis by assessing the multifaceted and controversial status of sika deer in Scotland, and the ethical connotations associated with their management. Unlike ancient hybrid zones, the process of hybridisation between red and sika deer in Scotland is still young, <120 years, making it unclear whether hybridising populations will stabilise to form a hybrid zone, merge or be separated by reinforcement and selection (Senn et al. 2010). Without management to reduce, prevent or stem further hybridisation, there remains a possibility of widespread introgression or complete admixture of the two taxa, leaving no pure remaining red deer on mainland Scotland. Cultural, conservation and economic repercussions of widespread introgression or complete admixture of red and sika populations would be significant. Further research to determine the likelihood of future outcomes, and what level of management is therefore necessary.

\section{Acknowledgements}

I would like to thank my project supervisor Aileen Mill at Newcastle University.

Allendorf FW, Lundquist LL (2003) Introduction: population biology, evolution, and control of invasive species.

Conservation Biology 17:24-30.

Arnold ML (1993) Iris nelsonii (Iridaceae): Origin and Genetic Composition of a Homoploid Hybrid Species. American Journal of Botany 80:577-583.

Arnold ML (1994) Natural Hybridization and Louisiana Irises. BioScience 44:141-147.

Aronson J, Clewell AF, Blignaut JN, Milton SJ (2006) Ecological restoration: A new frontier for nature conservation and economics. Journal for Nature Conservation 14:135-139.

Assessment ME (2005) Ecosystems and human well-being: biodiversity synthesis. Island Press. 
Association of Deer Management Groups < http://www.deermanagement.co.uk/dmgs/deer-management-groups/> [Accessed 16 February 2014]

Balharry E, Staines BW, Marquiss M, Kruuk H, Branch C (1994) Hybridisation in British mammals. JNCC Rep 154:1-42.

Barton NH (2001) The role of hybridization in evolution. Molecular Ecology 10:551-568.

Baskin Y (2002) A plague of rats and rubbervines: the growing threat of species invasions. Island Press.

Bateson P (1997) The behavioural and physiological effects of culling red deer. University of Cambridge.

Bateson P, Bradshaw EL (1997) Physiological effects of hunting red deer (Cervus elaphus). Proceedings of the Royal Society of London Series B: Biological Sciences 264:1707-1714.

Biedrzycka A, Solarz W, Okarma H (2012) Hybridization between native and introduced species of deer in Eastern Europe. Journal of Mammalogy 93:1331-1341.

BirdLife International 2012. Oxyura leucocephala. In: IUCN 2013. IUCN Red List of Threatened Species. Version 2013.2. <www.iucnredlist.org>. Downloaded on 7 April 2014.

Boecklen WJ, Howard DJ (1997) Genetic Analysis of Hybrid Zones: Numbers of Markers and Power of Resolution. Ecology 78:2611-2616.

Bourton J (2009) Scotland's deer are changing shape due to hybridisation

<http://news.bbc.co.uk/earth/hi/earth_news/newsid_841300 0/8413647.stm> [Accessed 15 April 2014]

Boitani L (1992) Wolf research and conservation in Italy. Biological Conservation 61:125-132.

Borkowski J (2000) Influence of the density of a sika deer population on activity, habitat use, and group size. Canadian Journal of Zoology 78:1369-1374.

Bradshaw EL, Bateson P (2000) Welfare implications of culling red deer (Cervus elaphus). Animal Welfare 9:3-24.

Bradshaw GA, Schore AN, Brown JL, Poole JH, Moss CJ (2005) Elephant breakdown. Nature 433:807-807.

Bremner A, Park K (2007) Public attitudes to the management of invasive non-native species in Scotland. Biological Conservation 139:306-314.

Butchart SHM (2008) Red List Indices to measure the sustainability of species use and impacts of invasive alien species. Bird Conservation International 18:S245.

Byrne RW, Bates LA (2011) Cognition in the wild: exploring animal minds with observational evidence. Biology Letters 7:619-622.

Cardinale BJ, Duffy JE, Gonzalez A, Hooper DU, Perrings C, Venail P, Narwani A, Mace GM, Tilman D, Wardle DA et al. (2012) Biodiversity loss and its impact on humanity. Nature 486:59-67.

Chapin Iii FS, Zavaleta ES, Eviner VT, Naylor RL, Vitousek PM, Reynolds HL, Hooper DU, Lavorel S, Sala OE, Hobbie SE et al. (2000) Consequences of changing biodiversity. Nature 405:234-242.

Clutton-Brock TH (1989) Red deer in the Highlands.

Code of Practice on Deer Management <http://www.snh.gov.uk/docs/B949709.pdf> [Accessed 20 April 2014]
Colautti R, Grigorovich I, MacIsaac H (2006) Propagule Pressure: A Null Model for Biological Invasions.

Biological Invasions 8:1023-1037.

Convention on Biological Diversity: Aichi Biodiversity Targets <http://www.cbd.int/sp/targets/> [Accessed 19 January 2014]

Convention on Biological Diversity (1992) <https://www.cbd.int/doc/legal/cbd-en.pdf> [Accessed 12 April 2014]

Crutzen P (2006) The “Anthropocene". In: Ehlers E, Krafft T (eds) Earth System Science in the Anthropocene. Springer Berlin Heidelberg, pp 13-18.

Deer (Scotland) Act $1996<$ http://www.legislation.gov.uk/ukpga/1996/58/contents> [Accessed 23 February 2014]

DEFRA (2012) Clampdown on dangerous dogs <https://www.gov.uk/government/news/clampdown-ondangerous-dogs $>$ [Accessed 7 April 2014]

Diaz A, Pinn E, Hannaford J (2005) 14. Ecological impacts of Sika Deer on Poole Harbour saltmarshes. In: Humphreys J, May V (eds) Proceedings in Marine Science, vol Volume 7. Elsevier, pp 175-188.

Endangered Species Act of $1973<$ http://www.epw.senate.gov/esa73.pdf > [Accessed 23 February 2014]

European Commission (2013) Commission Proposal for Regulation on invasive alien species http://eurlex.europa.eu/legalcontent/EN/TXT/PDF/?uri=CELEX:52013PC0620\&from= EN [Accessed 17 April 2014]

Executive S (2004) Scotland's biodiversity: it's in your hands-a strategy for the conservation and enhancement of biodiversity in Scotland. Edinburgh: Scottish Executive.

Geist V (2007) When do wolves become dangerous to humans?

Goodman SJ, Barton NH, Swanson G, Abernethy K, Pemberton JM (1999) Introgression through rare hybridization: A genetic study of a hybrid zone between red and sika deer (genus Cervus) in Argyll, Scotland. Genetics 152:355-371.

Gorman ML (2007) Restoring ecological balance to the British mammal fauna. Mammal Review 37:316-325.

Goudie AS (2013) The human impact on the natural environment: past, present, and future. John Wiley \& Sons.

Haanes H, Røed K, Mysterud A, Langvatn R, Rosef O (2010) Consequences for genetic diversity and population performance of introducing continental red deer into the northern distribution range. Conservation Genetics 11:1653-1665.

Hebblewhite M, White CA, Nietvelt CG, McKenzie JA, Hurd TE, Fryxell JM, Bayley SE, Paquet PC (2005) Human Activity Mediates a Trophic Cascade Caused by Wolves. Ecology 86:2135-2144.

Hewitt GM (2001) Speciation, hybrid zones and phylogeography - or seeing genes in space and time. Molecular Ecology 10:537-549.

Higgins P (2001) The Economic Contribution of Outdoor Recreation, Outdoor Education and Highland Sporting Estates to the Economy of Scotland. Education, Culture and Sport, Rural Development and Justice 2.

Hochberg ME, Gotelli NJ (2005) An Invasions Special Issue. Trends in Ecology \& Evolution 20:211. 
Hodder KH, Bullock JM (1997) Translocations of Native Species in the UK: Implications for Biodiversity. Journal of Applied Ecology 34:547-565.

Hodges SA, Burke JM, Arnold ML (1996) Natural Formation of Iris Hybrids: Experimental Evidence on the Establishment of Hybrid Zones. Evolution 50:2504-2509.

Hulme PE (2009) Trade, transport and trouble: managing invasive species pathways in an era of globalization. Journal of Applied Ecology 46:10-18.

Hussain AMT, Tschirhart J (2013) Economic/ecological tradeoffs among ecosystem services and biodiversity conservation. Ecological Economics 93:116-127.

Huxel GR, Hastings A (1999) Habitat loss, fragmentation, and restoration. Restoration Ecology 7:309-315.

John Ralph C, Maxwell BD (1984) Relative effects on human and feral hog disturbance on a wet forest in Hawaii. Biological Conservation 30:291-303.

Jr WHW (1970) Biosystematics and Evolutionary Noise. Taxon 19:146-151.

Kaji K, Okada H, Yamanaka M, Matsuda H, Yabe T (2004) Irruption of a colonizing sika deer population. Journal of Wildlife Management 68:889-899.

Kareiva P, Watts S, McDonald R, Boucher T (2007) Domesticated nature: shaping landscapes and ecosystems for human welfare. Science 316:1866-1869.

Katz E (2009) The big lie: human restoration of nature. Readings in the Philosophy of Technology:443.

Kelly, B.T., Beyer, A. \& Phillips, M.K. 2008. Canis rufus. In: IUCN 2013. IUCN Red List of Threatened Species. Version 2013.2. <www.iucnredlist.org>. Downloaded on 27 April 2014.

Kelly BP, Whiteley A, Tallmon D (2010) The Arctic melting pot. Nature 468:891-891.

King BJ (2013) When Animals Mourn. Scientific American 309:62-67.

Kirkpatrick M (2000) Reinforcement and divergence under assortative mating. Proceedings of the Royal Society of London Series B: Biological Sciences 267:1649-1655.

Kirkwood JK (1992) Wild animal welfare. In: Report of the Whale Welfare and Ethics Workshop. p 66.

Knobloch IW (1959) A Preliminary Estimate of the Importance of Hybridization in Speciation. Bulletin of the Torrey Botanical Club 86:296-299.

Kuwayama R, Ozawa T (2000) Phylogenetic relationships among European red deer, wapiti, and sika deer inferred from mitochondrial DNA sequences. Molecular phylogenetics and evolution 15:115-123.

Kyle CJ, Johnson AR, Patterson BR, Wilson PJ, White BN (2008) The conspecific nature of eastern and red wolves: conservation and management implications. Conservation Genetics 9:699-701.

Kymäläinen M, Oranen H, Pesonen J Economic impacts of Invasive Alien Species.

Largiadèr C (2007) Hybridization and Introgression Between Native and Alien Species. In: Nentwig W (ed) Biological Invasions, vol 193. Ecological Studies. Springer Berlin Heidelberg, pp 275-292.

Lévêque C, Mounolou J-C (2004) Biodiversity

Linnell JDC, Andersen R, Andersone Z, Balciauskas L, Blanco JC, Boitani L, Brainerd SM, Breitenmoser U, Kojola I, Liberg O (2002) The fear of wolves: a review of wolf attacks on people. NINA Oppdragsmelding 731: 65pp 731.

Lockwood JL, Cassey P, Blackburn T (2005) The role of propagule pressure in explaining species invasions. Trends in Ecology \& Evolution 20:223-228.

Lotsy JP (1916) Evolution by means of hybridization.

Lowe R (1994) Deer management: developing the requirements for the establishment of diverse coniferous and broadleaf forests. Unpublished Report, Coilte, Bray, Co Wicklow.

MacMillan D (2004) Tradeable hunting obligations - a new approach to regulating red deer numbers in the Scottish Highlands? Journal of Environmental Management 71:261270.

MacMillan D, Phillip S (2010) Can Economic Incentives Resolve Conservation Conflict: The Case of Wild Deer Management and Habitat Conservation in the Scottish Highlands. Human Ecology 38:485-493.

Macmillan DC, Phillip S (2008) Consumptive and nonconsumptive values of wild mammals in Britain. Mammal Review 38:189-204.

Mallet J (2005) Hybridization as an invasion of the genome. Trends in Ecology \& Evolution 20:229-237.

Mallet J (2008) Hybridization, ecological races and the nature of species: empirical evidence for the ease of speciation. Philosophical Transactions of the Royal Society B: Biological Sciences 363:2971-2986.

Manchester SJ, Bullock JM (2000) The impacts of non-native species on UK biodiversity and the effectiveness of control. Journal of Applied Ecology 37:845-864.

Manning AD, Gordon IJ, Ripple WJ (2009) Restoring landscapes of fear with wolves in the Scottish Highlands. Biological Conservation 142:2314-2321.

Marques FFC, Buckland ST, Goffin D, Dixon CE, Borchers DL, Mayle BA, Peace AJ (2001) Estimating deer abundance from line transect surveys of dung: sika deer in southern Scotland. Journal of Applied Ecology 38:349-363.

Matsunaga T, Chikuni K, Tanabe R, Muroya S, Nakai H, Shibata K, Yamada J, Shinmura Y (1998) Determination of mitochondrial cytochrome B gene sequence for red deer $(<$ i $>$ Cervus elaphus $</ i>$ ) and the differentiation of closely related deer meats. Meat science 49:379-385.

Mayr E (1970) Populations, species, and evolution: an abridgment of animal species and evolution. Harvard University Press.

McGeoch MA, Butchart SHM, Spear D, Marais E, Kleynhans EJ, Symes A, Chanson J, Hoffmann M (2010) Global indicators of biological invasion: species numbers, biodiversity impact and policy responses. Diversity and Distributions 16:95-108.

McKee JK (2005) Sparing nature: the conflict between human population growth and earth's biodiversity. Rutgers University Press.

McMahon CR, Harcourt R, Bateson P, Hindell MA (2012) Animal welfare and decision making in wildlife research. Biological Conservation 153:254-256.

McNeely JA (2001) Global strategy on invasive alien species. IUCN.

Mech LD (1995) The Challenge and Opportunity of Recovering Wolf Populations. Conservation Biology 9:270-278. 
Mech, L.D. \& Boitani, L. (IUCN SSC Wolf Specialist Group) 2010. Canis lupus. In: IUCN 2013. IUCN Red List of Threatened Species. Version 2013.2. <www.iucnredlist.org>. Downloaded on 7 April 2014.

Meyerson LA, Mooney HA (2007) Invasive alien species in an era of globalization. Frontiers in Ecology and the Environment 5:199-208.

Milton K (2000) Nature conservation as boundary maintenance. Natural enemies: People-wildlife conflicts in anthropological perspective:229.

Mims MC, Darrin Hulsey C, Fitzpatrick BM, Todd Streelman $\mathrm{J}$ (2010) Geography disentangles introgression from ancestral polymorphism in Lake Malawi cichlids. Molecular Ecology 19:940-951.

Mooney HA, Cleland EE (2001) The evolutionary impact of invasive species. Proceedings of the National Academy of Sciences 98:5446-5451.

Mullins J, Harrahill M (2008) Dog Bites: A Brief Case Review. Journal of Emergency Nursing 34:490-491.

Muñoz-Fuentes V, Green A, Negro J (2013) Genetic studies facilitated management decisions on the invasion of the ruddy duck in Europe. Biological Invasions 15:723-728.

Muñoz-Fuentes V, Green AJ, Negro JJ, Sorenson MD (2005) Population structure and loss of genetic diversity in the endangered white-headed duck, Oxyura leucocephala. Conservation Genetics 6:999-1015.

Muñoz-Fuentes V, VilÀ C, Green AJ, Negro JJ, Sorenson MD (2007) Hybridization between white-headed ducks and introduced ruddy ducks in Spain. Molecular Ecology 16:629-638.

Nentwig W, Kuehnel E, Bacher S (2010) A Generic Impact-Scoring System Applied to Alien Mammals in Europe. Conservation Biology 24:302-311.

Nilsen EB, Milner-Gulland EJ, Schofield L, Mysterud A, Stenseth NC, Coulson T (2007) Wolf reintroduction to Scotland: public attitudes and consequences for red deer management. Proceedings of the Royal Society B: Biological Sciences 274:995-1003.

Ninan KN (2006) The economics of biodiversity conservation: valuation in tropical forest ecosystems. Earthscan.

Pejchar L, Mooney HA (2009) Invasive species, ecosystem services and human well-being. Trends in Ecology \& Evolution 24:497-504.

Pérez-Espona S, Hall RJ, Pérez-Barbería FJ, Glass BC, Ward JF, Pemberton JM (2013) The Impact of Past Introductions on an Iconic and Economically Important Species, the Red Deer of Scotland. Journal of Heredity 104:14-22.

Perez-Espona S, Pemberton JM, Putman R (2009) Red and sika deer in the British Isles, current management issues and management policy. Mammalian Biology 74:247-262.

Pimentel D (2002) Biological invasions: economic and environmental costs of alien plant, animal, and microbe species. CRC Press.

Pimentel D, Lach L, Zuniga R, Morrison D (2000) Environmental and economic costs of nonindigenous species in the United States. BioScience 50:53-65.

Pimentel D, Zuniga R, Morrison D (2005) Update on the environmental and economic costs associated with alieninvasive species in the United States. Ecological Economics 52:273-288.
Polziehn RO, Strobeck C (1998) Phylogeny of wapiti, red deer, sika deer, and other North American cervids as determined from mitochondrial DNA. Molecular phylogenetics and evolution 10:249-258.

Putman RJ, Hunt EJ (1993) Hybridisation between red and sika deer in Britain. Deer 9:104-110.

Randi E (2008) Detecting hybridization between wild species and their domesticated relatives. Molecular Ecology 17:285-293.

Randi E, Lucchini V, Christensen MF, Mucci N, Funk SM, Dolf G, Loeschcke V (2000) Mitochondrial DNA variability in Italian and East European wolves: detecting the consequences of small population size and hybridization. Conservation Biology 14:464-473.

Ratcliffe PR (1987) Distribution and current status of sika deer, Cervus nippon, in Great Britain. Mammal Review 17:39-58.

Reaser JK, Meyerson LA, Cronk Q, De Poorter MAJ, Eldrege LG, Green E, Kairo M, Latasi P, Mack RN, Mauremootoo J et al. (2007) Ecological and socioeconomic impacts of invasive alien species in island ecosystems. Environmental Conservation 34:98-111.

Rhymer JM, Simberloff D (1996) Extinction by hybridization and introgression. Annual Review of Ecology and Systematics 27:83-109.

Ripple WJ, Beschta RL (2007) Restoring Yellowstone's aspen with wolves. Biological Conservation 138:514-519.

Ripple WJ, Beschta RL (2012) Trophic cascades in Yellowstone: The first 15years after wolf reintroduction. Biological Conservation 145:205-213.

Ripple WJ, Rooney TP, Beschta RL (2010) Large predators, deer, and trophic cascades in boreal and temperate ecosystems. Trophic cascades: Predators, prey, and the changing dynamics of nature:141-161.

Rosenfield JA, Nolasco S, Lindauer S, Sandoval C, Kodric-Brown A (2004) The role of hybrid vigor in the replacement of Pecos pupfish by its hybrids with sheepshead minnow. Conservation Biology 18:1589-1598.

Sagoff M (2005) Do Non-Native Species Threaten The Natural Environment? Journal of Agricultural and Environmental Ethics 18:215-236.

Schalamon J, Ainoedhofer H, Singer G, Petnehazy T, Mayr J, Kiss K, Höllwarth ME (2006) Analysis of dog bites in children who are younger than 17 years. Pediatrics 117:e374-e379.

Schlaepfer DR, Glättli M, Fischer M, van Kleunen M (2010) A multi-species experiment in their native range indicates pre-adaptation of invasive alien plant species. New Phytologist 185:1087-1099.

Schmitz OJ, Beckerman AP, O'Brien KM (1997) Behaviorally mediated trophic cascades: effects of predation risk on food web interactions. Ecology 78:13881399.

Scotland's Wild Deer: A National Approach (2008) <http://www.snh.gov.uk/docs/C249895.pdf> [Accessed 15 February 2014]

Seehausen O (2004) Hybridization and adaptive radiation. Trends in Ecology \& Evolution 19:198-207. Selge S, Fischer A, van der Wal R (2011) Public and professional views on invasive non-native species - A qualitative social scientific investigation. Biological Conservation 144:30893097. 
Senn HV (2009) Hybridisation between red deer (Cervus elaphus) and Japanese sika (C. nippon) on the Kintyre Peninsula, Scotland.

Senn HV, Barton NH, Goodman SJ, Swanson GM, Abernethy KA, Pemberton JM (2010) Investigating temporal changes in hybridization and introgression in a predominantly bimodal hybridizing population of invasive sika (Cervus nippon) and native red deer (C. elaphus) on the Kintyre Peninsula, Scotland. Molecular Ecology 19:910-924.

Senn HV, Pemberton JM (2009) Variable extent of hybridization between invasive sika (Cervus nippon) and native red deer (C-elaphus) in a small geographical area. Molecular Ecology 18:862-876.

Shurtliff QR (2013) Mammalian hybrid zones: A review. Mammal Review 43:1-21.

Simberloff D, Genovesi P (2013) Anthropocene: action makes sense. Nature 502:624-624.

Singer P (2011) Practical ethics. Cambridge university press.

Smith GC, Henderson I (2007) A model for the management of the invasive ruddy duck to reduce interbreeding pressure on the white-headed duck. International Journal of Pest Management 53:335-339.

Steffen W, Crutzen PJ, McNeill JR (2007) The Anthropocene: Are Humans Now Overwhelming the Great Forces of Nature? Ambio 36:614-621.

Steffen W, Grinevald J, Crutzen P, McNeill J (2011) The Anthropocene: conceptual and historical perspectives. Philosophical Transactions of the Royal Society A: Mathematical, Physical and Engineering Sciences 369:842-867.

Strong DR, Frank KT (2010) Human Involvement in Food Webs*. Annual Review of Environment and Resources 35:1-23.

Swanson G, Putman R (2009) Sika Deer in the British Isles. In: McCullough D, Takatsuki S, Kaji K Sika Deer. Springer Japan, pp 595-614.
Treweek J (2009) Ecological impact assessment. John Wiley \& Sons.

Verardi A, Lucchini V, Randi E (2006) Detecting introgressive hybridization between free-ranging domestic dogs and wild wolves (Canis lupus) by admixture linkage disequilibrium analysis. Molecular Ecology 15:2845-2855.

Vilà C, Wayne RK (1999) Hybridization between Wolves and Dogs. Conservation Biology 13:195-198.

Vitousek PM, D'Antonio CM, Loope LL, Rejmanek M, Westbrooks R (1997) Introduced species: a significant component of human-caused global change. New Zealand Journal of Ecology 21:1-16.

Wildlife and Countryside Act 1981 (Variation of Schedules 5 and 8) Order $1998<$ http://www.legislation.gov.uk/uksi/1998/878/made> [Accessed 17 March 2014]

Wildlife and Natural Environment (Scotland) Act 2011 <http://www.legislation.gov.uk/ukpga/1996/58/contents> [Accessed 3 April 2014]

Wilson CJ (2004) Could we live with reintroduced large carnivores in the UK? Mammal Review 34:211-232.

Wilson EO (1999) The diversity of life. WW Norton \& Company.

Wirtz P (1999) Mother species-father species: unidirectional hybridization in animals with female choice. Animal behaviour 58:1-12.

Woodroffe R, Thirgood S, Rabinowitz A (2005) People and wildlife, conflict or co-existence? Cambridge University Press.

Yalden D (2010) The history of British mammals. A\&C Black.

Zachos FE, Hartl GB (2011) Phylogeography, population genetics and conservation of the European red deer Cervus elaphus. Mammal Review 41:138-150. 